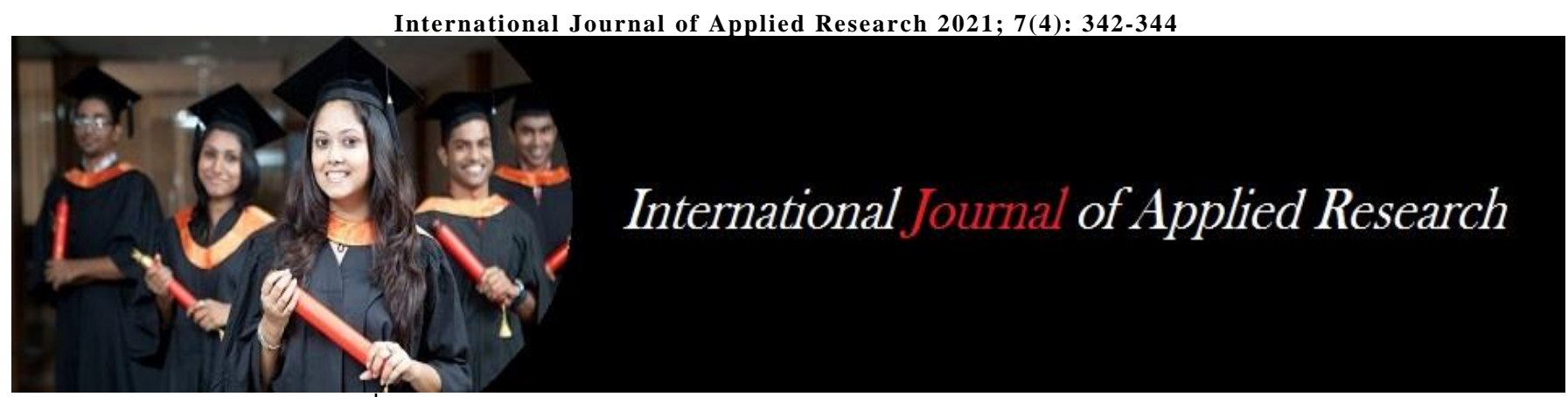

ISSN Print: $2394-7500$

ISSN Online: 2394-5869

Impact Factor: 8.4

IJAR 2021; 7(4): 342-344

www.allresearchjournal.com

Received: 02-02-2021

Accepted: 30-03-2021

Shyamal Acharya

Ph.D., Research Scholar,

Seacom Skills University, West

Bengal, India

\section{Application of MI theory to a law classroom}

\section{Shyamal Acharya}

DOI: https://doi.org/10.22271/allresearch.2021.v7.i4e.8519

\section{Abstract}

ELT in India is vivid and dynamic today. The total teaching paradigm has changed through spell by spell. In order to address the need for different teaching strategies, we must first realize there are different learning styles for different class students. Howard Gardner, the American Psychologist, was aware of this when he developed his remarkable theory of Multiple Intelligence. This article traces how Multiple Intelligence (MI) theory touches off a wave of educational innovation in a law classroom. Being an English Language teacher in a Law College, I find the basic concepts of MI theory conform to my interest in "individualized instruction" and "independent learning".

Keywords: ELT with ripple effect, MI theory, Law students

\section{Introduction}

In the closing years of the $20^{\text {th }}$ century when English language began to emerge as the world language, the Indian classroom was transformed because of the change in the environment of the learner whereas the earlier surroundings had been acquisition poor with regard to English, suddenly every language user seemed to be jumping upon the learn-English bandwagon. The liberalization of Indian economy invited in all kinds of causes to learn the language. In previous times students who had specialized in English joined either teaching or the civil services, now a new spectrum of job opportunities has opened up. New generation come to gain the law certificate and try to maintain their lifestyle by using it.

Educators started paying attention to the impact that learners' affective factors (e.g. their feelings, emotions, tension, anxiety, frustration, demands, motivation, confidence, interests etc.) may bring to the process of learning. Language teaching matured by some innovative ELT methods, approaches and techniques during the 70s to the 80s, such as The Silent Way, Community Languages Learning (CLL), Total Physical Response (TPR), The Natural Approach, Suggestopedia, Interactive Learning, Cooperative Learning, Task-based learning, The Whole Language Learning and others.

\section{Multiple intelligence theory}

In the old time, intelligence was a fixed, static, entity at birth which was defined operationally as the ability to answer items in IQ tests. Dr. H. Gardner has bestowed an alternative significance of intelligence based on a radically different view of intelligence. According to Dr. H. Gardner, an intelligence entails the ability to solve problems or fashion products that are of consequence in a particular cultural setting or community (1993:15). There are many, not just one, different but autonomous intelligence capacities that result in many different ways of knowing, understanding and learning about our globe. As Dr. H. Gardner (1993:12) states:

It is of the utmost importance that we recognize and nurture all of the varied human intelligences, and all of the combination of intelligence. We are all so different largely because we all have different combinations of intelligences. If we recognize this, I think we will have at least a better chance of dealing appropriately with the many problems that we face in the world.

In order to make a clear distinction between intelligence with its biological origin and a talent/ skill, Dr. Gardner states that each intelligence must satisfy all or a majority of the following criteria, namely brain damage studies, exceptional individual developmental history, evolutionary history, psychometric findings, psychological tasks, core operations and symbol system (Christison, 1998). 
According to Dr. H. Gardner, there are eight kinds of intelligence that requires teachers to adjust their instructional strategies in order to meet students' individual needs.

The first of Gardner's intelligences is Verbal/ Linguistic. Verbal intelligence co-links with the mastery of language. It is the ability to use language effectively and creatively both orally and in writing. Their ability to manipulate language lends then to fields such as teaching, journalism, writing, law, and translation. Language enables them to be better at memorizing information. Verbal students are often great lawyers or storytellers. The linguistic intelligence enables one to pay special attention to grammar and vocabulary.

Logical/ Mathematical Intelligence consists of the ability to detect patterns, reason deductively, and think logically. It also consists for all forms of currently existing standardized testing programmes.

Visual/ Spatial intelligence co-relates with the ability to sense form, space, colour, line, and shape including the ability to graphically represent visual/ spatial ideas. It can be involved in such people/ students as architects, cartographer, visual artist (Sculptors); yet blind people/ students also can form spatial intelligence.

Musical/ Rhythmic Intelligence involves the ability to use sound to the greatest extent possible. It can be seen in advertising professionals, performance musicians, dance brands and composers, rock musicians and others.

Bodily/ Kinesthetic Intelligence is the ability to control bodily movements and to handle objects skillfully. Athletes, dancers and actors exhibit bodily/ kinesthetic intelligence.

Interpersonal Intelligence has the ability to study others' moods, temperaments, and intentions. This form of intelligence is usually highly developed in such people as teachers, counselors, politicians and religious leaders.

Intrapersonal intelligence co-relates with the ability to understand the internal aspects of the self and to practice self-discipline.

Naturalist learners (Intelligence) love the outdoors and enjoy classifying and categorizing activities. This intelligence can be seen in such people as farmers, hunters, zookeepers, gardeners, nature guide, and forest- rangers.

\section{The application of MI theory to law students}

Gardner's MI theory bestows broader intellectual spectrum in every student. Being a lecturer of a law college, aware of the fact that every students of a law classroom bring with them specific strengths, havoc learning styles, and different learning potentials. The MI Theory eyes a path to examine and form best teaching strategies and methods in the light of human differences. I can teach the law students in many ways by using MI Theory. Applying the Theory within a classroom means that teachers are free to show artistic expression interpersonal communication, and physical movement abilities in addition to the standard reading, writing and speaking. MI Theory makes an opportunity for students to explore the range of intellectual abilities and to develop talents in areas of intellectual strengths. I come up with the list bellow:

\section{Step 1}

Finding student's strengths (every student has some of each of all intelligences, but in different students one [or more] is more pronounced) and apply Learner type Linguistic. Vocabulary and Grammar learning (learning new words and grammatical points and practicing using them accurately in regular communication), a formal and informal speaking (making verbal presentation to others, making conversation), a reading, writing, speaking (silent reading, oral reading, and group/ chain reading for comprehension, note-taking, summary/ report, notice writing help to keep track of one's own thoughts and ideas) - all types of format are very applicable to law-students.

\section{Step 2}

If we apply combined thought of Musical Intelligence and Logical Intelligence to a law classroom then it will be very effective. Jazz chants/ rapping (raps to help communicate, or to remember certain words, sentence structures, concepts, ideas, or processes) and a forming relationship or a logical presentation (creating meaningful connections between different ideas, or inventing point-by-point logical explanations for items or making systematic presentation of subject matter) and so on are very fruitful for law students.

\section{Step 3}

To a law student, the Interpersonal Intelligence is very applicable. As a future lawyer, she/ he should adopt of the ability to understand, perceive and discriminate between people's mood, feelings, motives, and intelligences. Interpersonal Intelligence shares many of its characteristics with Intrapersonal Intelligence. It deals more with the individual self.

\section{A lesson plan for law student}

How MI theory applies to classroom teaching, I draw a lesson plan on the topic titled: "Language Training: A Content-Based Reading, A Text Book Used, for reference."

\section{$1^{\text {st }}$ Period: Classroom activities}

1. Presenting the background knowledge about the topic and its author. 10 minutes. Linguistic/ Verbal (through lecture)

2. Instant question making, that is, what was the aim of the author in writing this topic? And/ or, what does the title indicate to you? 15 minutes. Linguistic/ Verbal (through informal speaking) interpersonal, intrapersonal.

3. Listening to the topic to grasp the main ideas. 5 minutes. Linguistic/ Verbal (through listening)

4. Oral reading and silent reading for making the central thought from each paragraph. 25 minutes. Verbal/ Linguistic (through reading)

5. Vocabulary learning through the strategy of guessing meaning from context or form. 15 minutes. Verbal/ Linguistic (through vocabulary and vocabulary learning strategies)

\section{$2^{\text {nd }}$ Period: classroom activities}

1. Group discussion (G.D.) on the basis of main thought of each paragraph and revision of its main idea. 20 minutes. Verbal/ Linguistic (through discussion), interpersonal and logical.

2. Doing exercises either orally/ in writing by working in groups and/ or individually. 30 minutes Verbal/ Linguistic (through speaking or writing) and interpersonal.

3. Drawing the comment on the concept/ ideas one agrees or disagrees in the topic, and showing reasons of his / 
her. 15 minutes. Verbal/ linguistic (through oral presentation) and intrapersonal.

4. Telling the synonyms and antonyms of the collecting new English words or phrases from the given topic and also telling the Latin/ Greek/ French terms similar in meaning to this new word or phrase to the students (Latin Maxims or Legal Maxims, Latin words, phrases and etcetera are very essential for law students). It is the activities of the ELT expert in a Law classroom (through oral presentation) 15 minutes.

\section{Conclusion}

There are several paths which may facilitate the implementation of MI theory in our classroom:

1. Test our intellectual corners and search our own teaching strategies through MI theory

2. Understand the intellectual profiles of our students

3. Consider specific teaching method or approach

4. Use MI theory through classroom activities with a solid pre-plan

5. Must think about the future life of the students.

Only in doing, so can teachers fully encourage their learners to try harder and at the same time make the learning environment as meaningful and enjoyable as possible for all parties involved.

\section{References}

1. Campbell B. The Multiple Intelligences Handbook: Lesson Plans and More, Stanwood. WA: Campbell and Associates, Inc 1994.

2. Chitty C. Differing Views of Human Intelligence. Forum 2011;53(2):235-246

3. www.wwwords.co.uk/FORUM http://dx.doi.org/10.2304/forum.2011.53.2.235.

4. Drudy S, Lynch K. Schools and Society in Ireland. Dublin: Gill \& Macmillan 1993.

5. Fleischmann A. Presentation Order Multiple Intelligences Project. Paper to $18^{\text {th }}$ Annual conference of the Educational Studies Association of Ireland, Galway, March 1998.

6. Flynn M. Extending the Limits: The Possibilities of Multiple Intelligences Theory for Equality. Unpublished Ph.D. thesis, University College Cork 2000.

7. Fogarty RJ, Stoehr J. Integrating curricula with multiple intelligences, teams, themes, \& threads. Thousand Oaks, CA: Corwin Press 2008.

8. Freire P. Pedagogy of Freedom: Ethics, Democracy and Civic Courage. (Clarke, P.) 1998.

9. Gardner's Multiple Intelligence Theory. (April 16, 2001)

10. http://www.scibory.uwaterloo.ca/tboogara/physics/GMIT/html

11. Intelligence in seven steps- Howard Gardner

12. http://www.newhorizons.org/future/creating_the Future/crfut_gardner...

13. Multiple Intelligences: The Making of a Modern Myth, DANIEL T. WILLINGHAM

14. http://www.catholiceducation.org/articles/education/ed0 226.html 